\title{
TEMPORAL EVOLUTION OF URBAN GROWTH AND ITS IMPACT ON RUNOFF RATES GENERATION
}

\author{
A. JODAR-ABELLAN ${ }^{1}$, J. VALDES-ABELLAN ${ }^{1,2}$, C. PLA ${ }^{1,2} \&$ F. GOMARIZ-CASTILLO ${ }^{3}$ \\ ${ }^{1}$ University institute of Water and Environmental Sciences, University of Alicante, Spain. \\ ${ }^{2}$ Department of Civil Engineering, University of Alicante, Spain. \\ ${ }^{3}$ Euro-Mediterranean Water Institute, University of Murcia, Spain.
}

\begin{abstract}
The province of Alicante (SE Spain) is the fourth most populated region in Spain, with 1.9 million inhabitants. Additionally, tourism is one of the most important industries of the region since the sixties of the last century. Tourism industry attracts more than 3.4 million tourists and 14.5 million overnight stays per year, mainly in summer.

Urban development has expanded as a consequence of that demographic pressure, mainly in the coastal areas. At present time, there are examples of watersheds with ephemeral streams where more than half of the complete area is occupied by urban soil.

This urban development has increased the existing high hydrological hazard, since the hydrological answer of watersheds to a precipitation event has moved to higher flow rate peaks and shorter concentration times. Urban planning policy makers have to face that problem urgently since the main climate features of this geographic area are the very intense and localized rainfalls, which fall specially in the months of September, October and November. Then, the ravines beds, which remain dry during the majority of the year, are forced to lead high amounts of water in a clear case of flash floods.

In the present study, we analyse the temporal evolution of the hydrological response of a small watershed as a consequence of the urban growth. Hydrological dynamics were accomplished with the ArcGIS tool and the SWAT hydrological model. Changes in soil uses have been analysed through GISbased tools, with soil use coverage information for the different study periods. Main results show that study area (Amerador watershed) has duplicated its urban area since 1990 (31.62 ha) to 2012 (61.07 ha) increasing the risk of flooding in a coast urban zone with low runoff thresholds $\left(0 \mathrm{l} / \mathrm{m}^{2}-7.5 \mathrm{l} / \mathrm{m}^{2}\right)$ and discharges that reach $190 \mathrm{~m}^{3} / \mathrm{s}$.
\end{abstract}

Keywords: flash floods, land use, Mediterranean ephemeral streams basins, SWAT, urban development

\section{INTRODUCTION}

Currently, flash floods are one of the main risks that human beings have to face. These phenomena produce some of the most sever natural problems, causing destruction to property, infrastructures and even sometimes arouses loss of human life (Rozalis et al. [1]). This situation is particularly common in certain areas such as Southeast of Spain. Here these episodes constitute a potential threat; flash floods occur because of the inherent features of Mediterranean climate and are emphasized due to the high vulnerability of the territory characterised by the intense urbanization and occupation related to the touristic activity. This great urbanization is located mainly in the coastline of the Mediterranean basins (CamarasaBelmonte [2]).

This work is focused in the province of Alicante (SE Spain), where downpours are considerably heterogeneous. Generally, rainfall amount varies between 30 and $70 \mathrm{~mm}$ (DPA-IGME [3]) but eventually some precipitation episodes surpass $100 \mathrm{~mm}$ (Rozalis et al. [1]; ValdésAbellán et al. [4]). These climatic particularities have not been correctly considered due to the fact that on the last 3-4 decades the coastline of the Alicante province has suffered a large urban development, often without a suitable urban development plan. This problem has derived in highly vulnerable conditions and has increased the risk of flooding. 
The study area, Amerador ravine, is located in the municipalities of El Campello and Aigües. This area represents a typical fluvial system, with ephemeral streams, of Mediterranean and semi-arid basins. The region, with moderately steep slopes have many basins in which rainfall water concentrates with short concentration times, causing dangerous situations.

The objective of the study is to analyse the temporal evolution of the discharge rates along time as a consequence of changes in cover land uses, mainly due to tourism. To get this objective, firstly, the runoff threshold of the mentioned watershed was obtained at a spatial resolution of hydrological response unit. Next, a design storm was generated and finally, the watershed response to this storm was obtained by the use of SWAT model with a sub-daily time step. These objectives were performed in four land use scenarios in order to assess the impact of urban development in the basin.

\section{STUDY AREA}

The study basin is the Amerador ravine, located mainly in the municipality of El Campello. The northern part of the watershed is situated in the Aiguies municipality (province of Alicante, SE Spain). This area presents 19 subbasins with a total surface of $14.22 \mathrm{~km}^{2}$ (Fig. 1).

Study area is situated in the eastern part of the Cordilleras Béticas (Sistema Prebético). It is characterised by a certain lithological diversity with materials from the Jurassic, Tertiary and Quaternary periods (DPA-IGME [3]).

The climate is classified as Mediterranean subtropical dry and semi-arid with scarce, irregular and random precipitations. The summer drought varies from 3 to 5 months, but there are days with high-intensity rainstorms (Valdés-Abellán et al. [4]; DPA-IGME [3]).

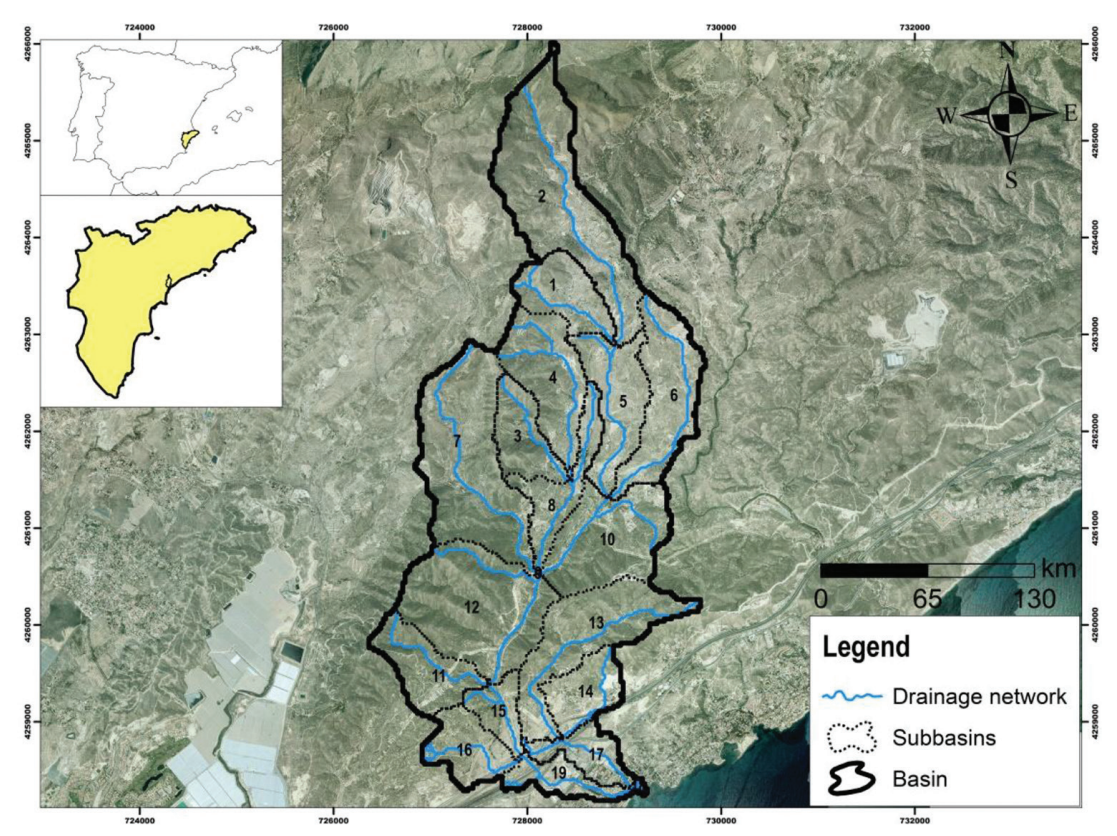

Figure 1: Study area: Amerador ravine basin with an area of $14.22 \mathrm{~km}^{2}$ and 19 subbasins. 


\section{METHODOLOGY}

The methodology of the present work is divided in two main sections with regard to the above mentioned objectives.

\subsection{Runoff threshold}

The runoff threshold in the Amerador ravine basin was calculated according to the 5.2-IC Spanish normative [5]. Land use cover, permeability and slope data were analysed with the ArcGIS tool in order to obtain the runoff threshold.

Land use was obtained from the Geographic Information National Center (CNIG [6]). The Corine Land Cover (CLC) database, with a scale 1:100,000, was used. CLC data from the periods 1990, 2000, 2006 and 2012 was considered, generating four scenarios: CLC1990, CLC2000, CLC2006 and CLC2012.

Permeability coverage was obtained from the Spanish Geological Survey (IGME) in shapefile format (scale 1:50,000).

Slope cover data was calculated from the digital elevation model (DEM), in raster format, available on CNIG [6], with an accuracy of $25 \mathrm{~m}$ x $25 \mathrm{~m}$. In line with the methodology shown in Tarboton et al. [7], DEM25 was pre-filtered using ArcGIS tool to remove sinks and peaks.

As a result of this process, the watershed shapefile polygons of runoff threshold was obtained at a spatial resolution of hydrological response unit (Neitsch et al. [8]). Four scenarios of runoff threshold were generated dependent on the four land use scenarios.

\subsection{Streamflow}

The average sub-daily streamflow out of each subbasin was calculated using the SWAT model (Arnold et al. [9]; Winchell et al. [10]), version 2012.10.2.18, as a coupled extension to ArcGIS tool (ArcSWAT). In order to carry out this model, the following hydrological input data were used:

\subsubsection{Cover Data}

Amerador basin and subbasins were delineated based on the DEM available on CNIG [6], with a spatial resolution of $25 \mathrm{~m}$ x $25 \mathrm{~m}$. To remove sinks and peaks, DEM25 was pre-filtered with ArcGIS according to Tarboton et al. [7]. This is recommended to ensure a proper delineation of basin, subbasins and streams and to avoid the generation of a discontinuous drainage network in the watershed. To improve the mentioned delineation, the drainage network layer, scale 1:25,000 in shapefile format, modified from the Pfafstetter national river classification [11], was also used. Therefore, a correct flow transmission between different subbasins was obtained. With these layers, 19 subbasins were generated in the study watershed. The output basin was fixed next to the Mediterranean Sea.

The generated subbasins were subdivided into hydrologic response units (HRUs) that present similar land use, slope, and soil characteristics (Neitsch et al. [8]). In order to obtain HRUs, the raster cover data of soils available in Harmonized World Soil Database (HWSD), with a scale of 1:1,000,000 [12], was used. The soil codes from HWSD were adapted and included into the SWAT2012 database. The slope was divided into two classes $(0 \%-3 \%$ and $>3 \%$ ) following the 5.2-IC Spanish normative [5]. Land use coverage was obtained from the above-mentioned Corine Land Cover (CNIG [6]) considering the four scenarios of 1990, 2000, 2006 and 2012. Different hydrologic response units were obtained for each scenario: 
93 HRUs in CLC1990, 88 HRUs in CLC2000, 88 HRUs in CLC2006 and 81 HRUs in CLC2012. In these four scenarios, CLC land use classes were reclassified into SWAT land use classes according to El-Sadek and Irvem [13]. The mentioned reclassifications are shown in Table 1.

\subsubsection{Meteorological data}

The time of concentration $\left(T_{c}\right)$ is considered as "the amount of time from the beginning of a rainfall event until the entire subbasin area is contributing to flow at the outlet" (Neitsch et al. [8]). This variable was calculated for the Amerador watershed using the 5.2-IC Spanish normative [5] which expression is shown in eqn (1).

$$
T_{\mathrm{c}}=0.3 \cdot L_{\mathrm{c}}^{0.76} \cdot J_{\mathrm{c}}^{-0.19}
$$

where $T_{c}$ is the time of concentration (hours); $L_{c}$ is the channel length $(\mathrm{km})$; and $J_{c}$ is the average slope of the channel (\%).

A $T_{c}$ of 2.91 hours was obtained in the Amerador watershed. Using this value and the precipitation daily series from the 8025-Alicante_Ciudad Jardin meteorological station (period 1981-2016), a synthetic rainfall was generated (design storm), considering a time step of 10 minutes and a return period of 100 years. Maximum and minimum daily temperatures were also obtained from the mentioned meteorological station (period 1981-2016). Therefore, potential evapotranspiration was simulated with the Hargreaves method (Hargreaves et al. [14]).

Table 1: Corine Land Cover land use classes reclassified into SWAT land use classes. 1990, 2000, 2006 and 2012 scenarios.

\begin{tabular}{|c|c|c|c|}
\hline $\begin{array}{l}\text { CLC } \\
\text { Code }\end{array}$ & Definition & SWAT Code & Definition \\
\hline 112 & Discontinuous urban fabric & URML & $\begin{array}{l}\text { Residential-Med/ } \\
\text { low Density }\end{array}$ \\
\hline 121 & Industrial or commercial units & UCOM & Commercial \\
\hline 122 & Road and rail networks and associated Land & UTRN & Transportation \\
\hline 212 & Permanently irrigated land & AGRC & $\begin{array}{l}\text { Agricultural land- } \\
\text { close-grown }\end{array}$ \\
\hline 222 & Fruit trees and berry plantations & ORCD & Orchard \\
\hline 231 & Pastures & PAST & Pasture \\
\hline 242 & Complex cultivation patterns & AGRL & Agricultural land- \\
\hline 243 & $\begin{array}{l}\text { Land principally occupied by agriculture, } \\
\text { with significant areas of natural vegetation }\end{array}$ & & generic \\
\hline 312 & Coniferous forest & FRSE & Forest-Evergreen \\
\hline 321 & Natural grassland & RNGE & Range-Grasses \\
\hline 323 & Sclerophyllous vegetation & & \\
\hline 324 & Transitional woodland-shrub & FRST & Forest-Mixed \\
\hline 523 & Sea and ocean & WATR & Water \\
\hline
\end{tabular}




\subsubsection{Velocity of flow and flood propagation}

Water routing along main and tributary channels of the Amerador watershed was accomplished using Manning and Muskingum methods. Manning's equation for uniform flow was used to calculate the rate and velocity of flow in these channels for a given time step (eqn 2).

$$
q_{c h}=\frac{A_{c h} \cdot R_{c h}^{2 / 3} \cdot s l p_{c h}^{1 / 2}}{n}
$$

where $q_{c h}$ is the rate of flow in the channel ( $\left.\mathrm{m}^{3} / \mathrm{s}\right) ; A_{c h}$ is the cross-sectional area of flow in the channel $\left(\mathrm{m}^{2}\right) ; R_{c h}$ is the hydraulic radius for a given depth of flow $(\mathrm{m}) ; s l p_{c h}$ is the slope along the channel length $(\mathrm{m} / \mathrm{m})$; and $n$ is the Manning's roughness coefficient for the channel (Manning et al. [15]). In the Amerador watershed an average Manning's coefficient of 0.022 was chosen corresponding to the channel category of "Earth, straight and uniform" fixed in Chow [16].

Water was routed through the channel network using the Muskingum river routing method (Cunge [17]; Overton [18]) whose main expression is represented in eqn 3.

$$
V_{\text {stored }}=K \cdot\left(X \cdot q_{\text {in }}+(1-X) \cdot q_{\text {out }}\right)
$$

where $V_{\text {stored }}$ is the storage volume $\left(\mathrm{m}^{3} \mathrm{H}_{2} \mathrm{O}\right) ; K$ is the storage time constant for the reach segment $(\mathrm{s}) ; q_{\text {in }}$ is the inflow rate $\left(\mathrm{m}^{3} / \mathrm{s}\right) ; q_{\text {out }}$ is the discharge rate $\left(\mathrm{m}^{3} / \mathrm{s}\right)$; and $X$ is a weighting factor that controls the relative importance of inflow and outflow in determining the storage in a reach. According to Neitsch et al. [8], a weighting factor of 0.2 was assigned in the Amerador watershed channels. Regarding the storage time constant $(K)$, this variable depends on two calibration coefficients that control the impact of high flow $\left(K_{c o 1}\right)$ and low flow $\left(K_{c o 2}\right)$. Attending to the channel characteristics of the Amerador ravine basin, values of 0.25 for $K_{c o l}$ and 0.75 for $K_{c o 2}$ were used in this study.

\subsubsection{Run the SWAT sub-daily model}

After including previous data in SWAT, the model was run with a sub-daily time step of 10 minutes. To calculate the amount of precipitation on a wet day, an exponential distribution with an exponent of 1.3 was used. This distribution is most commonly used in regions with limited available data on rainfall events (Neitsch et al. [8]).

In order to obtain the model outputs with a time interval of 10 minutes, some files (Basins. bsn, File.cio, and so one) were modified from TxtlnOut folder to re-run the SWAT model.

Finally, results were obtained in the flowout variable defined as "the average sub-daily streamflow out of each main channel or reach, in $\mathrm{m}^{3} / \mathrm{s}$, per subbasin" (Arnold et al. [19]).

\section{RESULTS AND DISCUSSION}

The main results obtained in this study are shown in the following sections:

\subsection{Runoff threshold}

The land use cover data and the runoff threshold for the four scenarios stablished in the Amerador ravine basin are shown in Fig. 2.

In the four scenarios, runoff threshold levels vary considerably depending on agricultural or urban land use due to the fact that urban coverage generates an almost impermeable surface (Fig. 2). Consequently, urban areas experiment high rainfall-surface runoff conversions 

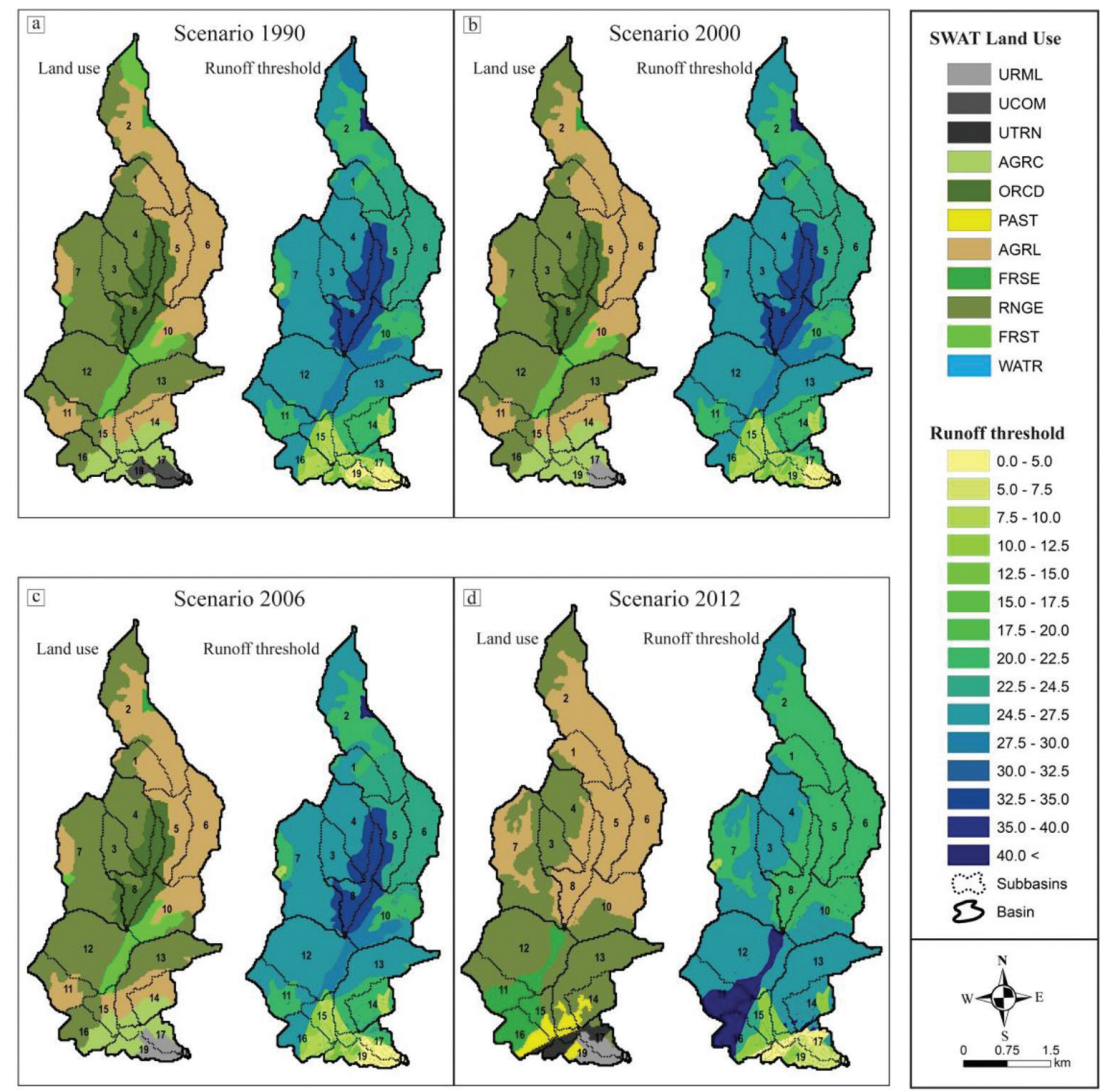

Figure 2: Runoff threshold rates (mm) of the Amerador watershed with the different land use scenarios (CLC1990, CLC2000, CLC2006 and CLC2012).

generating flash floods and related problems (Camarasa-Belmonte [2]). In the study basin, runoff threshold of urban areas varies from $01 / \mathrm{m}^{2}$ to $7.51 / \mathrm{m}^{2}$ while agricultural zones present ranges between $10 \mathrm{l} / \mathrm{m}^{2}$ and $47 \mathrm{l} / \mathrm{m}^{2}$. However, into the agricultural and urban categories, different land use classes show similar runoff thresholds. For example, agricultural classes of AGRL (Agricultural land-generic) and RNGE (Range-Grasses) produce respectively runoff thresholds variable from $22 \mathrm{l} / \mathrm{m}^{2}$ to $25 \mathrm{l} / \mathrm{m}^{2}$ in the four land use scenarios.

Regarding to the surface occupied by urban areas, a high growth during the study period (1990-2012) was observed. The Amerador watershed presented 31.62 ha in 1990 and 61.07 ha in 2012 (Fig. 2). This urban growth, performed with no accurate guidance from any urban development plan, increases the risk of flash food and reduces the runoff thresholds.

\subsection{Streamflow}

The sub-daily discharge rates $\left(\mathrm{m}^{3} / \mathrm{s}\right)$ generated into the Amerador subbasins present variances according to flow propagation and land use coverage (Fig. 3). These results have been analysed in three main subbasins located in the headwaters of the Amerador watershed (subbasin 2), in the middle of the basin (subbasin 10) and in the outlet of the complete basin placed next to the Mediterranean Sea (subbasin 18). 


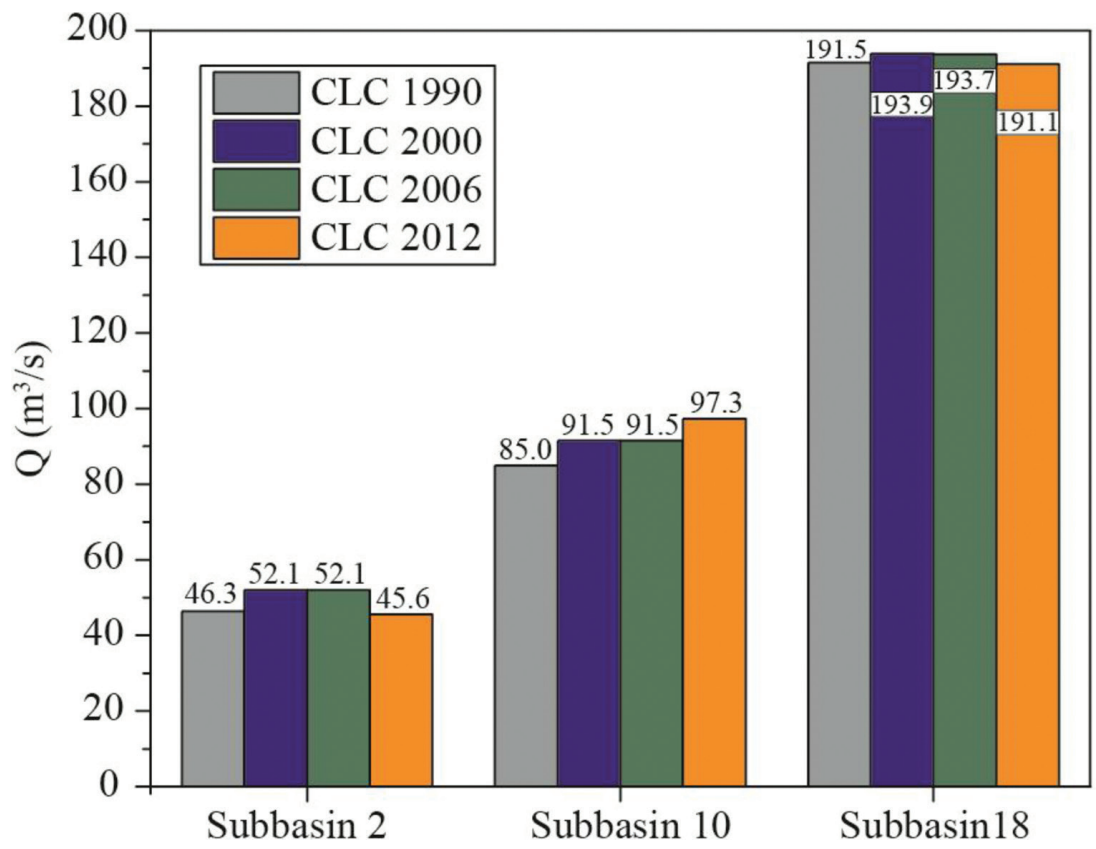

Figure 3: Maximum discharge $\left(\mathrm{m}^{3} / \mathrm{s}\right)$ with the different land use scenarios. Subbasins 2,10 and 18.

Results show little variation in each subbasin (Fig. 3) due to the fact that different agricultural and urban land use covertures produce similar discharge. However, flow presents great changes between subbasins because flow propagation along the main and tributary channels of the watershed generates high discharge rates downstream. In the subbasin 18, these flow rates are also increased on account of urban land use that waterproofs the surface terrain (Fig. 3). As shown in Fig. 4, in subbasin 2, the peak runoff rate occurs at 2.4 hours after the start of the generated sub-daily storm while this peak runoff rate reaches the subbasin 18 three hours later than the beginning of the rainfall event.

\section{CONCLUSIONS}

The main conclusions extracted from the present study are listed below:

- The Amerador watershed has duplicated its urban area since 1990 (31.62 ha) to 2012 (61.07 ha) without a sensible criterion to the consequences on the flood hazard.

- This great urban growth has derived in highly vulnerable situations and has increased the risk of flooding in a coastal urban areas with low runoff thresholds $\left(01 / \mathrm{m}^{2}-7.51 / \mathrm{m}^{2}\right)$.

- After generating a design storm with a return period of 100 years, the discharges $\left(\mathrm{m}^{3} / \mathrm{s}\right)$ obtained in the urban zone of the Amerador watershed (subbasins 18, 19 and so one) reach $190 \mathrm{~m}^{3} / \mathrm{s}$.

- Moreover, in the four scenarios considered, there are important variances in runoff thresholds and discharges generated between different land uses categories (urban or agricultural). However, into each category, urban and agricultural land use classes produce similar runoff thresholds and discharges. For example, urban coverage of URML 


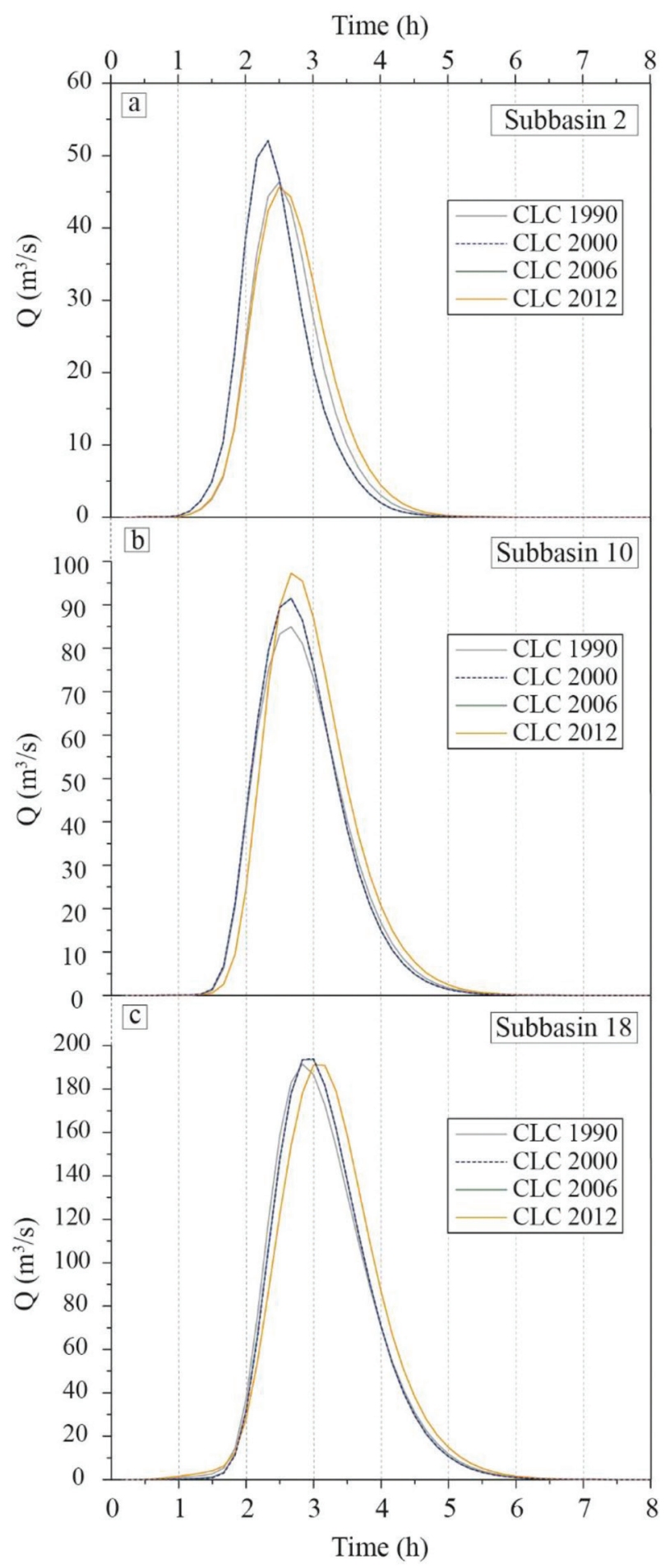

Figure 4: Storm hydrographs with the different land use scenarios. Subbasins 2, 10 and 18. 
(Residential-Med/low Density) and UCOM (Commercial) create both of them runoff thresholds between $01 / \mathrm{m}^{2}$ and $51 / \mathrm{m}^{2}$ in the four scenarios stablished.

- Implemented tools (ArcGIS and the SWAT hydrological model) have been proved to be correct to perform the study objectives. The SWAT model will allow accomplishing further research in the study watershed and in contiguous basins. These lines will assess impacts derived from different agricultural practices on water resources, water quality, contamination of surface and subsurface water and their consequences to urban and tourism development.

\section{ACKNOWLEDGEMENTS}

Financial support was provided partially by the University of Alicante, project GRE15-19. This study also has been conducted within the grant received from the Programa Nacional de Formación de Profesorado Universitario (FPU) conceded by the Spanish Ministry of Science to the first author. In the same way, the authors acknowledge the reviewers of the manuscript whose comments contributed greatly to improve this paper.

\section{REFERENCES}

[1] Rozalis, S., Morin, E., Yair, Y. \& Price C., Flash flood prediction using an uncalibrated hydrological model and radar rainfall data in a Mediterranean watershed under changing hydrological conditions. Journal of Hydrology, 394(1), pp. 245-255, 2010. https://doi.org/10.1016/j.jhydrol.2010.03.021

[2] Camarasa-Belmonte, A.M., Flash floods in Mediterranean ephemeral streams in Valencia Region (Spain). Journal of Hydrology, 541, pp. 99-115, 2016. https://doi.org/10.1016/j.jhydrol.2016.03.019

[3] DPA-IGME, Atlas hidrogeológico de la provincia de Alicante, Excelentísima Diputación Provincial de Alicante (DPA), Área de Ciclo Hídrico-Instituto Geológico y Minero de España (IGME): Alicante, pp. 1-284, 2015.

[4] Valdes-Abellan, J. Pardo, M.A. \& Tenza-Abril, A.J., Observed precipitation trend changes in the western Mediterranean region. International Journal of Climatology, 37 (S1), pp. 1285-1296, 2017. https://doi.org/10.1002/joc.4984

[5] 5.2-IC Spanish normative, Proyecto de Orden Ministerial por la que se aprueba la Norma 5.2-IC Drenaje Superficial de la Instrucción de Carreteras, BOE: Madrid, pp. 1-182, 2015.

[6] CNIG (Geographic Information National Center), available at http://centrodedescargas .cnig.es/CentroDescargas/buscadorCatalogo.do?codFamilia=02107 (accessed 28 November 2017)

[7] Tarboton, D.G., Bras, R.L. \& Rodriguez-Iturbe, I., On the extraction of channel networks from digital elevation data. Hydrological Processes, 5(1), pp. 81-100, 1991. https://doi.org/10.1002/hyp.3360050107

[8] Neitsch, S.L., Arnold, J.G., Kiniry, J.R. \& Williams, J.R, Soil and Water Assessment Tool. Theorical Documentation. Version 2009. Texas Water Resources Institute: Texas, pp. 1-647, 2011.

[9] Arnold, J.G., Srinivasan, R., Muttiah, R.S. \& Williams, J.R., Large area hydrologic modeling and assessment Part I: Model development. JAWRA Journal of the American Water Resources Association, 34(1), pp. 73-89, 1998. https://doi.org/10.1111/j.1752-1688.1998.tb05961.x 
[10] Winchell, M., Srinivasan, R.S., Di Luzio, M. \& Arnold, J.G, ArcSWAT Interface for SWAT2012. User's Guide, Texas Water Resources Institute: Texas, pp. 1-464, 2013.

[11] MAPAMA. Tramos de ríos de España clasificados según Pfafstetter modificado, available at http://www.mapama.gob.es/es/cartografia-y-sig/ide/descargas/agua/ red-hidrografica.aspx (accessed 29 November 2017)

[12] HWSD. Harmonized World Soil Database Laxemburg, available at http://webarchive .iiasa.ac.at/Research/LUC/External-World-soil-database/HTML/ (accessed 17 November 2017)

[13] El-Sadek, A. \& Irvem, A., Evaluating the impact of land use uncertainty on the simulated streamflow and sediment yield of the Seyhan River basin using the SWAT model. Turkish Journal of Agriculture and Forestry, 38(4), pp. 515-530, 2014. https://doi.org/10.3906/tar-1309-89

[14] Hargreaves, G.L., Hargreaves, G.H. \& Riley, J.P., Agricultural benefits for Senegal River Basin. Journal of Irrigation and Drainage Engineering, 111(2), pp. 113-124, 1985.

https://doi.org/10.1061/(asce)0733-9437(1985)111:2(113)

[15] Manning, M.J., Sullivan, R.H. \& Kipp, T.M., Characterization of Discharges. Nationwide Evaluation of Combined Sewer Overflows and Urban Stormwater Discharges, Environmental Protection Agency: Cincinnati (US), pp. 107, 1977.

[16] Chow, V.T., Open-Channel Hydraulics, McGraw-Hill Civil Engineering Series: New York, pp. 1-680, 1959.

[17] Cunge, J.A., On the subject of a flood propagation computation method (Muskingum Method). Journal of Hydraulic Research, 7(2), pp. 205-230, 1969. https://doi.org/10.1080/00221686909500264

[18] Overton, D.E., Muskingum flood routing of upland streamflow. Journal of Hydrology, 4, pp. 185-200, 1966. https://doi.org/10.1016/0022-1694(66)90079-5

[19] Arnold, J.G., Kiniry, J.R., Srinivasan, R., Williams, J.R., Haney, E.B. \& Neitsch, S.L., Input/Output Documentation Version 2012, Texas Water Resources Institute: Texas, pp. 1-650, 2012. 